\title{
Mîrzâ Âkâ Hân-ı Kirmânî’nin Sultan Abdülhamid'e Takdim Ettiği Rıdvân Adlı Farsça Eseri ${ }^{1}$
}

\author{
Çetin KASKA \\ Arş. Gör. Dr., İstanbul Üniversitesi \\ Edebiyat Fakültesi, Fars Dili ve Edebiyatı Bölümü \\ cetinkaska@hotmail.com \\ Orcid ID: https://orcid.org/0000-0002-1168-5522
}

Öz

Malazgirt zaferinden sonra Anadolu Selçukluları, Anadolu Beylikleri ve Osmanlı Devleti dönemlerinde devlet adamlarının sağladığı güvenli ve huzurlu ortam sayesinde birçok yazar, şair, edip ve âlim İran, Irak, Orta Asya'dan Anadolu topraklarına göç etmiştir. Bu seçkin kimseler hem ders vermiş, hem de edebî ve dinî eserler yazarak Anadolu'nun ilim ve kültür merkezi haline gelmesine yardımcı olmuştur. Bunlardan biri de Kaçarlar döneminde Osmanlı topraklarına zorunlu olarak göç eden Mîrzâ Âkâ Hân-1 Kirmânî'dir. Âkâ Hân on yıldan fazla İstanbul'da kalmış ve Sa'dî-i Şîrâzî'nin Gülistân adlı eserini taklit ederek, Rldvân adında manzum ve mensur bir eser yazmış ve Sultan Abdülhamid'e takdim etmiştir. Âkâ Hân'ın 1887'de İstanbul'da tamamladığı bu eser bir dîbâce, mufassal bir mukaddime, dört bölüm ve bir hâtimeden oluşmaktadır. Eserde toplam 353 manzum ve mensur yazılmış hikâye yer almaktadır. Âkâ Hân'ın yaklaşık yirmi beş yaşındayken yazmaya başladığı bu edebî eserde Sultan Abdülhamid ve Münif Paşa iyilikle yâd edilmiştir. Bu makalede Mîrzâ Âkâ Hân'ın yazdığı Rıdvân adlı eser Türkiye'de ilk defa detaylı ele alınıp incelenmiştir.

Anahtar Kelimeler: Mîrzâ Âkâ Hân-i Kirmânî, Rıdvân, Sultan Abdülhamid, Gülistân, Farsça.

\section{Mirza Aqa Khan Kermani's Perisan Book Titled Ridvan, Presented to Sultan Abdulhamid}

\begin{abstract}
After the victory of Malazgirt, many writers, poets, and scholars migrated from Iran, Iraq, Central Asia to Anatolian lands thanks to the safe and peaceful

\footnotetext{
${ }^{1}$ Makale Geliş/Kabul Tarihi: 18.05.2020 / 29.01.2021

Künye Bilgisi: Kaska, Ç. (2021). Mîrzâ Âkâ Hân-i Kirmânî’nin Sultan Abdülhamid’e takdim ettiği Rıdvân adlı Farsça eseri. Kahramanmaraş Sütçü İmam Üniversitesi Sosyal Bilimler Dergisi, 18 (1), 351-374. DOI: 10.33437/ksusbd.739185
} 
environment provided by statesmen during the Anatolian Seljuks, Anatolian Principalities and the Ottoman Empire. These distinguished people both taught and helped Anatolia become a center of science and culture by writing literary and religious works. One of them is Mirza Aqa Khan Kermani who immigrated to Ottoman lands during the Kadjars period. Aqa Khan stayed in Istanbul for more than ten years and wrote a verse and prose work named Ridvan and presented it to Sultan Abdulhamid by imitating the work named Gulistan by Saadi Shirazi. This work, completed by Aqa Khan in Istanbul in 1887, consists of a preface, a detailed introduction, four chapters and a conclusion. There are a total of 353 verse and prose stories written in the work. Sultan Abdulhamid and Munif Pasha were praised in this literary work that Aqa Khan started when he was only twentyfive years old. Mirza Aqa Khan's book Ridvan in this article have been investigated for the first time in Turkey.

Keywords: Mirza Aqa Khan Kermani, Ridvan, Sultan Abdulhamid, Gulistan, Persian.

\section{GíRIŞ}

Türk devletleri Fars dili ve edebiyatına ilgi göstermiş ve bu dil ve edebiyatla eserler yazanlar himaye edilmiştir. Fars dili ve edebiyatına olan ilgi Gazneli Devleti'nde başlamış, Büyük Selçuklu Devleti, Anadolu Selçukluları, Anadolu Beylikleri, Osmanlı Devleti ve Türkiye Cumhuriyeti dönemlerinde devam etmiş̧tir. Selçuklu Devleti'nin kurulmasıyla İran kültürü Anadolu'ya taşınmıştır. Moğol istilasından sonra bu etkileşim oldukça hızlanmıştır. Memleketleri Moğollar tarafindan yakılıp yıkılan çok sayıda İranlı edip, şair ve âlim Anadolu'ya sığınmış ve Selçuklu Devleti'nin hizmetine girmiştir. Bu ilim adamları daha sonra İran kültürünün Anadolu'da canlanmasında rol oynamıştır. Şahıs, meslek ve yer isimlerinde Farsça kelimelerden istifade edilmiş, hukukî, dinî kayıtlarda ve resmî vesikalarda Farsça kullanılmıştır. Bu dönemde Anadolu şehirlerinde tasavvuf, tarih, edebiyat ve felsefe konusunda pek çok Farsça eser telif edilmiştir. Mevlânâ, Sultan Veled ve Sadreddin-i Konevî’nin etkisiyle Konya, Kayseri, Kırşehir, Amasya, Niğde, Sivas ve Erzincan'da çok sayıda Farsça eser telif veya istinsah edilmiştir. Farsça, Osmanlı Devleti'nin ilk bir buçuk yüzyılında Türkçe'nin gelişmesi ve Arapça'nın canlanmasıyla Selçuklu dönemine oranla etkisini önemli ölçüde kaybetmiştir. Buna rağmen Yavuz Sultan Selim ve II. Bayezid dönemlerinde Osmanlı sultanları tekrar Farsça'ya ilgi göstermiştir. Hayatlarının ilk dönemlerinde iyi bir eğitim alan Osmanlı sultanları edebiyat dili olarak Farsça'yı ve ilim dili olarak Arapça'yı öğrenmiştir. Bazı Osmanlı sultanlarının Farsça şiir yazdıkları bilinmektedir. Cem Sultan, Kanuni Sultan Süleyman, Şehzade Bayezid, Yavuz Sultan Selim, Sultan III. Murad'ın Farsça divan ve divançeleri günümüze ulaşmıştır. Osmanlı döneminde de İran, Irak ve Orta Asya'dan birçok şair, yazar ve edip yöneticilerin sağladığı güvenli 
ortam nedeniyle Anadolu'ya göç etmiş̧ir. Göç eden bu seçkin kişilerden biri de Mîrzâ Âkâ Hân-1 Kirmânî’ dir. Âkâ Hân, Osmanlı topraklarında ders vermiş, Türkçe öğrenmiş, gazetelerde yazılar yazmış, eserler istinsah etmiş ve kitaplar yazmıştır (Değirmençay, 2013: 1-30; Aydın, 2010: 9-19; Riyâhî, 1995: 13-245; Kartal, 2008: 95-168; Özgüdenli, 2008: 1-76). Bu makaledeki Farsça parçaların tercümeleri yapılırken çoğunlukla kaynak esere sadık kalınmış ve birebir çeviri yapılmıştır, ancak anlaşılması zor kısımlarda serbest çeviriye başvurulmuştur.

\section{MîRZÂ ÂKÂ HÂN KİRMÂNî}

Âkâ Hân 1270'te Kirmân'ın Meşîz vilayetinde doğmuştur. Kirmân'da eğitimini tamamlamış, edebiyat, fikıh, felsefe, kelâm, hadis, mantık, usul ve tarih gibi konularda dersler almış, Fransızca ve Pehlevice dillerini öğrenmiştir. Kirmân'da 1881'de maliye memuru olmuş, bu görevi ifa ederken Kirmân Valisi Nâsırüddevle ile anlaşmazlık yaşamış ve İsfahan'a gitmek zorunda kalmıştır. İsfahan'da Şeyh Ahmed-i Rûhî ile arkadaş olmuş ve vali Ali Mîrzâ Zıllüssultan'ın yanında çalışmıştır. İsfahan'da Kirmân valisi kendisini rahatsız edince, arkadaşı Şeyh Ahmed ile birlikte Tahran'a gidip, valiyi hükümete şikâyet etmiş, ancak bunda bir netice elde edememiştir. Âkâ Hân, Tahran'da tefsir dersleri vermiş, Şeyh Mehdî Şerîf-i Kâşânî ve Yahya Devletâbâdî gibi ilim adamlarıyla görüşmüştür. Tahran'da rahat bırakılmayan Âkâ Hân, arkadaşı Şeyh Ahmed ile birlikte Meşhed, Reşt, Tebrîz yoluyla İstanbul'a gelmiş ve Bâbîlik inancı ile ilgilenmiş, arkadaşı Şeyh Ahmed ile birlikte Kıbrıs'a gidip, Bâbî lideri Mîrzâ Yahyâ Subhiezel ile görüşmüştür. Kıbrıs'ta Subhiezel'in kızıyla evlenmiş ve Şam'a seyahat etmiş, İstanbul'da bir ara İran elçisi Muhsin Han Muînülmülk ile birlikte Tahran'a gitmiştir. İranlıların İstanbul'da Farsça olarak çıkardığ 1 Ahter gazetesinde İran hükümetini eleştiren yazılar yazmış ve elçi ile arası bozulmuştur (Kurtuluş, 2016: 59-60; Âdemiyyet, 1346: 24-26).

Âkâ Hân, İstanbul'da birçok İranlı şair ve yazar ile tanışmış, devrin önemli ilim adamlarından Mîrzâ Habîb-i İsfahânî’nin evinde kalmış ve çok sayıda eser tashih etmiştir. İstanbul'daki İranlılara ait okulda bir süre ders vermiş (Kaska, 2019: 538-551), Londra'da İran elçisi Melkum Han'ın 1890'da çıkardığı Kânûn gazetesinde yazılar yazmış, Rıza Paşa, Halil Ethem, Sadık Han Selmâsî ve Clement Imbault gibi meşhur kimselere Fars dili ve edebiyatı alanında ders vermiştir. Âkâ Hân, İstanbul'da İngilizce ve Türkçe öğrenmiş ve Fransızcasını geliştirmiştir. Âkâ Hân, Mîrzâ Melkum Hân, Cemâleddîn-i Efgânî ve Mîrzâ Feth Alî Ahundzâde'den etkilenmiştir. Yazdığı yazılar ve Bâbîlik taraftarlı̆̆ 1 neticesinde İran hükümetinin hışmına uğramış, 1895 'te Ermeni isyanını teşvik ettikleri gerekçesiyle Osmanlı hükümeti tarafindan Şeyh Ahmed-i Rûhî ve Mîrzâ Hasan Hân Habîrülmülk gibi arkadaşlarıyla birlikte tutuklanmış ve 1895'te Trabzon'a gönderilmiştir. Daha sonra Nâsırüddin Şah, Bâbî olduğu söylenen bir kişi tarafindan öldürülünce, Âkâ Hân ve iki arkadaşı suçlu bulunup, İran'a teslim 
edilmiş ve 1896 'da Tebrîz'de idam edilmişlerdir. Âkâ Hân'ın Âyîne-i İskenderî, Rıdvân, Nâme-i Bâstân, Hikmet-i Nazarî, Ceng-i Haftâd u Dû Millet, Se Mektûb ve Sad Hitâbe, Terceme-i Ahdnâme-i Mâlik Eşter, Dîvân, Heşt Behişt, Tekvin ve Teşrîi, İnşallâh û Maşallâh ve Reyhân adlı eserleri vardır (Âryanpûr, 1387: 391; Kurtuluş, 2016: 59-60; Âdemiyyet, 1346: 24-26).

\section{RIDVÂN}

Mîrzâ Âkâ Hân-1 Kirmânî’ye ait olan bu eser, Sa 'dî’nin Gülistân adlı eserinden esinlenilerek yazılmıştır. Âkâ Hân, İran'da Kaçarlar hükümeti döneminde yaşamıştır. Bu dönem şairleri Horasan ve Irak üslupları şairleri olan Firdevsî, Unsurî, Muizzî, Sa dî, Hâfiz, Menûçihrî, Ferruhî, Hâkânî-yi Şirvânî ve Evhadüddîn-i Enverî tarzında şiirler yazmıştır. Şairlerin takip ettiği bu üsluba bazgeşt-i edebî denilmiştir. Bu dönemde edebiyat ve şiir pazarı revaç kazanmış, dinî inanç ve akideler yeni mazmunlarla ifade edilmiştir. Bâzgeșt-i edebî üslubu şairi Mîrzâ Âkâ Hân-1 Kirmânî, bu eseri Kirmân'da yirmi beş yaşındayken, yani 1295 'te yazmaya başlamış ve 1304 'te İstanbul'da tamamlamış ve Sultan Abdülhamid'e takdim etmiştir. Rıdvân, Âkâ Hân'ın ilk eseridir ve Âkâ Hân bu eserde Ubeyd-i Zâkânî’nin Risâle-i Dilgoşâ ve Ahlâkü'l-Eşrâf adlı eserlerinden iktibaslar yapmıştır. Âkâ Hân, Ayîne-i İskenderî ve Nâme-i Bâstân adlı eserlerinin aksine bu eserde hamasî mevzulardan çokça bahsetmemiş, daha çok padişaha nasihat tarzındaki konulara değinmiştir. Sa'dî, Gülistân'da İran'ın hicri yedinci yüzyıl sosyal ve ictimaî durumunu ifade etmiş, Âkâ Hân ise Rıdvân'da Osmanlı ve İran'ın hicri on üçüncü yüzyıldaki durumuna değinmiştir. Âkâ Hân, İran'da o dönem insanlarının tanıdığı Tahran Cuma namazı imamı, Şeyh Hâdî-i Necmâbâdî, Horasan hâkimi Âsafü'l-ddevle, Hâcî Pîrzâde, Yağmâ-i Cendekî, sadrazam Mişîrü'l-ddevle gibi kimselerden bahsetmiş, Sa'dî gibi adalet meselesine özel bir önem vermiş ve eserinin üçüncü babında bu mevzuya yer vermiştir. Sa'dî 41 hikâyeden oluşan Gülistân'ın ilk babında, yani padişahların hal ve hareketleri adlı bölümde 27 hikâyede eleştirel bir nazarla padişaha ve kudret sahiplerine bakmıştır. Âkâ Hân da 68 kısma ayrılan Rıdvân'ın üçüncü babında, yani büyüklerin sîreti ve meliklerin adabı adlı bölümdeki 64 hikâye ve dört hikmette, Sa'dî’nin eserinin ilk babındaki gibi daha çok padişahı eleştirmiş ve ona öğüt vermiştir. Rldvân'ın 1327 tarihli bir nüshası İran Meclis-i Şûrâ-i İslâmî Kütüphanesi'nde yer almaktadır (Dilgoşâ, 1394: 248-268; Serefzârî \& Dilgoşâ, 2015: 45-59; Oğûlbîg, 1388; 17-21; Muhammedî, 1383: 417-419).

Âkâ Hân, Rldvân'ın dîbâcesinde Sa'dî-i Şîrâzî'nin Gülistân adlı eserindeki gibi Allah'a hamd ve sena etmiş, ona şükretmenin mümkün olmadığını, onun cömertlik sofrasından herkesin istifade ettiğini belirtmiştir (Oğûlbîg, 1388: 35):

$$
\begin{aligned}
& \text { جون نتوان كرد ادا حق شكر * بنده مسكين جه كند با خداى } \\
& \text { ز آن كه يكى شكر نكفته هنوز * شكر دكر بايدش آرد به جاى }
\end{aligned}
$$




$$
\text { ایه كه از خوان جود و احسانت * ريزه خور اند منعم و درويش }
$$

“Şükrün hakkı eda edilemiyorsa, miskin kul Allah’a karşı nasıl davranmalı.

Daha bir şükrü eda etmeden başka bir şükrü eda etmesi gerekir.

Ey ihsan ve cömertlik sofrandan, derviş ve zenginin kırıntı yediği.

Ne alçağı kendinden ümitsiz edersin ne de kimseyi kapından kovarsın.”

Âkâ Hân, Allah'tan sonra, kâinatın en şereflisi olan Peygamberimizin vasıflarını dile getirmiştir (Oğûlbîg, 1388: 35):

$$
\text { شفيق، عطوف، لطيف, نسيم* نذير ، بشير، رسول، كريم }
$$

"Şefkatli, sevecen, latif, yumuşak huylu, yol gösterici, müjdeleyici, elçi ve kerimdir."

Rıdvân, Gülistân gibi secili bir nesir ile yazılmış, ancak bazı hikâyelerde insicam yoktur. Eser bir dîbâce, ayrıntılı bir mukaddime, bir hatime ve dört mevsim olarak adlandırılan dört babtan oluşmaktadır. Mukaddime: Nefislerin saadeti ve kötü günlerin değişimi. 1-Birinci mevsim (birinci bab): Aşk, hüsün ve gençliğin gerekliliklerini beyan etme. 2-İkinci mevsim (ikinci bab): Ahlakı pak etmek, talep ve istemenin neticesi. 3-Üçüncü mevsim (üçüncü bab): Büyüklerin sîreti ve meliklerin adabı. 4-Dördüncü mevsim (dördüncü bab): Karşı1lklı konuşmanın latifesi ve gülmenin ışığı. Hâtime: Ayetleri okumanın ve ibretli ibarelerle uğraşmanın hikmeti (Oğûlbîg, 1388: 42; Dilgoşâ, 1394: 248-268).

Âkâ Hân, Rıdvân'ın telif sebebini şöyle ifade etmiş: Arkadaşlarıyla bir gün yine gezinti yeri olan Sâdâbâd'da karşılaştığını ve oradaki yeşillik ve tazelikten eser kalmadığını görünce şaşırdığını ve ibret aldığını, Sa'dî’nin Gülistân'ından geçen "Geçici olan her şeye gönül bağlamak uygun değildir." ibaresini oradaki arkadaşlarına söylediğini ve arkadaşlarının kendisine bu fani âlemde Gülistân tarzında bir eser yazıp, bakî bir eser bırakmasını tavsiye ettiklerini ifade etmiştir (Oğûlbîg, 1388: 39):

$$
\begin{aligned}
& \text { با جمعى از يار انم باز در آن صحر ا تصادف شد. از آن نضارت و خضارت اثرى بر جاى نبود. }
\end{aligned}
$$

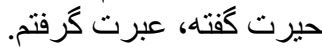

$$
\begin{aligned}
& \text { دل منه بر جر خ كَردون مدارش* نى ديش باينده بينى، نى بهارش }
\end{aligned}
$$

“Arkadaşlarımdan oluşan bir toplulukla yine bir gün Sâdâbâd'da karşılaş̧ık. Ancak orada yeşillik ve canlılıktan bir eser yoktu, hayret edip ibret aldım. 
Bu felek ve dünyaya gönül bağlama, ne zenginliği payidardır ne de baharı.”

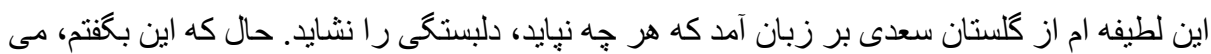

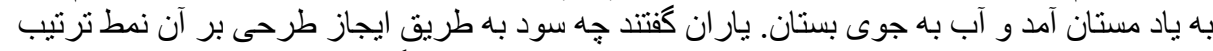

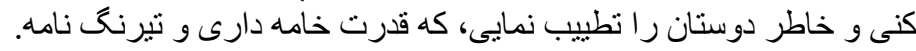

$$
\begin{aligned}
& \text { كنون كه فرصت كفتارت اى بر ادرت هست* جر ا به نشر و بيان سخن نمى كوشى؟ }
\end{aligned}
$$

“Sa'dî’nin Gülistân' inda geçen “Geçici olan her şeye gönül bağlamak uygun değildir." adlı latifeyi söyleyince, şarap sarhoşların ve su, ırmak yapanların hatırına geldi. Arkadaşlar dediler ki, dostlarının hatırını hoş edip, Gülistân'ı örnek alıp, bir eser yazman senin için faydalı olmaz mı, hem kalemin kuvvetli hem de yazı erbabisin.

Ey kardeş, şimdi senin söz söyleme zamanındır, niçin söz söylemeye çalışmıyorsun?"

Âkâ Hân dostlarına duyduğu saygıdan dolayı onların isteğini geri çevirmediğini, daha önce yazılan kıssalardan, hikâyelerden, atasözlerinden, menkıbelerden, öğüt ve nasihatlerden istifade ederek Rıdvân'1 ilkbaharda yazmaya başladığını ve sonbahar rüzgârı eserken onu tamamladığını belirtmiştir. Kısaca kitabın telif sürecine işaret etmiştir (Oğûlbîg, 1388: 40):

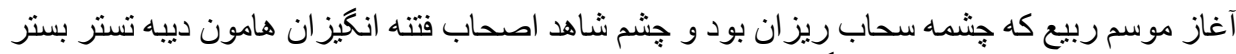

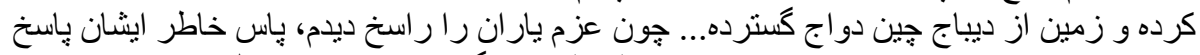

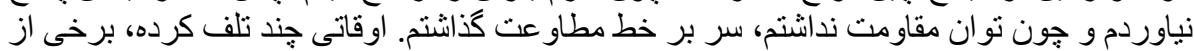

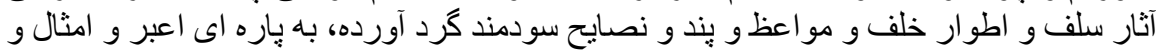

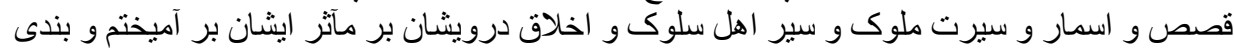

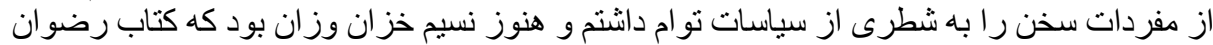

$$
\begin{aligned}
& \text { تمام شد. } \\
& \text { در خلد نعيم كردم باز * وين كتاب لطيف را آغاز } \\
& \text { تا به كى خاطرت به بستانها است* كه به رضوان من كلستانها است } \\
& \text { كل ز باد خزان شود ريزان* باغ رضوان هميشه جاويدان }
\end{aligned}
$$

“İlkbahar mevsiminin başıydı ve çeşme cömertçe akıyordu, fitne yayan sevgililerin güzel gözü ipek elbise giymişti ve zemin ipekten oluşan elbisesini yere sermişti... Dostların isteğini sağlam ve uygun bulunca, onlara duyduğum saygıdan dolayı cevap vermedim, ayrıca onlara karşı koyacak gücüm de yoktu. Onların isteğini kabul ettim. Bir süre vaktimi telef ettim, daha önce yazılmış eserlerden ve onları yazanların tarzlarından, vaaz, öğ̈t ve faydalı nasihatlerden istifade ettim, rüya tabirlerinden, ata sözlerden, kıssalardan, hikâyelerden, padişahların davranışlarından, dervişlerin ahlakından, tarikat ehli kimselerin seyr 
ü sulûk serüveninden yararlandım ve siyasi düşünceleri kısmen de olsa eserimde beyan ettim, daha sonbahar rüzgârı eserken Rıdvân kitabını bitirdim.

Rahman olan Allah'ın cennet kapısını açtım ve bu latif kitaba başladım.

Hatıran bostanlarda olduğu sürece, Rıdvân'ım gül bahçesi gibi kalacak.

Gül sonbahar rüzgârından dökülmeye başladı, ancak Rıdvân bahçesi sürekli daimi kaldı."

Âkâ Hân bu eseri 1304'te tamamladığını, manzum ve mensur olarak kaleme aldığını, Yunan felsefesinden bahsettiğini, amacının fazilet ve mükemmellikler yerine edep ve öğüt olduğunu ifade etmiştir (Oğûlbîg, 1388: 42):

$$
\begin{aligned}
& \text { در آن سالى كه رضوان مختتم شد * هزار و سيصد و جهارش رقم شد } \\
& \text { همه مقصود ما بند و ادب بود* نه اظهار كمالات و حسب بود } \\
& \text { جه حكت هاى يونانى كه كفتيم * جه كَّ هر هاى عمانى كه سفتيم } \\
& \text { اكر نايد به كُش رغبت كس* ز ما ابلاغ حكمت باتثد و بس هـ }
\end{aligned}
$$

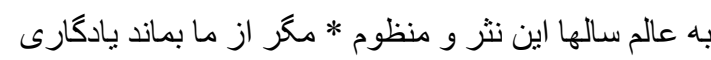

“Rıdvân tamamlandığında yıl 1304'dü gösteriyordu.

Bütün hedefimiz edep ve öğüttü, mükemmellikler ve fazileti beyan etmek değildi.

Hem Yunan asıllı hikmetlerden bahsettik, hem de Ummanlı mücevherler bulduk.

Bu eseri bir kimse duymaya meyletmese bile, bizden hikmetle bahsetmesi kâfidir.

Bu manzum ve mensur eser, âlemde bizden hatıra olarak yıllarca kalacak.”

Âkâ Hân, Abdülhamid'i zamanın halifesi, İslam Cumhuriyetleri sultanı, adil ve ihsan sahibi hafız, ilim ve irfanın hamisi, karaların sultanı, denizlerin hakanı ve ülkenin iftiharı gibi hitaplarla yâd etmiştir (Oğûlbîg, 1388: 38):

$$
\text { خوت البرين و خاقان سلطان جمهورى البلاميان، خافظ عدل و احسان، حامى علم و عرفان، سلطان }
$$




$$
\text { هى كاسمها دار السماده مالها* فى ميدان الوجود مدانى }
$$

"Zamanın halifesi, İslam Cumhuriyetleri sultanı, ihsan ve adil hafız, ilim ve irfan hâmîsi, karaların sultanı ve denizlerin hakanı...

Sultan Abdülhamid-i Sânî ülkenin iftiharı ve en soylu kimsedir.

Aynen adı gibi mutluluk kaynağıdır ve varlık meydanındaki madenin özüdür.”

Âkâ Hân, Abdülhamid sayesinde insanların emniyet ve güvende olduğunu, bütün mümin ve Frenklerin adetlerini serbestçe yerine getirdiğini, halkın kargaşa ve izdihamdan uzak olduğunu ve başka ülkelerdeki savaşçıların ülkesini yurt edindiğini beyan etmiştir (Oğûlbîg, 1388: 36):

$$
\begin{aligned}
& \text { لطف خداى حافظش از نايبات دهر * جندان كه حفظ خاطر بيجاركان كند } \\
& \text { همواره مردمان همه جفتند با امان * ز آن مردمى و لطف كه با مردمان كند } \\
& \text { ندانى جر ا از اقاليم عالم* به ملك تو دارند مردم درنكى } \\
& \text { ز بوم خود آواره كردند آنان* كه دارند در مغز خود هوش و هنكى } \\
& \text { به شهر تو جسته زر سو توطن* امير ان كثور دليران جنگى } \\
& \text { ز هندى و تازيك و رومى و مصرى* فرنكى و ناتار و جينى و زنكى } \\
& \text { از آن رو كه جفتند با امن و ايمان* از آنرو كهدورندز آثوب و تنكى } \\
& \text { همه مومنان كرده اجر ایى آيين * فرنگان ادا كرده رسم فرنكى }
\end{aligned}
$$

“Allâh'ın lütfu, onu zamanın kötülüklerinden aynı biçarelerin hatırını koruduğu gibi korusun.

İnsanların hepsi daima insanlara lütfeden o sultandan emniyet buldu.

Dünya ülkelerindeki insanların senin mülküne neden gelmede geciktiğini anlamiyorsun,

Oysa o ülkelerde, akıl ve idrak sahibi kimseleri yurtlarından derbeder ettiler.

Savaşçı cesur ülkelerin emirleri, şehrinin her tarafını yurt edindi.

Hintli, İranlı, Rumlu, Mısırlı, Tatar, Çinli, Avrupalı, Zengibarlı,

Sayende emniyet ve güvendeler ve sayende kargaşa ve izdihamdan uzaklar. 
Bütün müminler merasimlerini yapıyor, bütün Frenkler Frenklik adetlerini yerine getiriyor.”

Âkâ Hân, Sultan Abdülhamid'den sonra İran sultanı Muhammed'i övmüş, ülkesinin daimi, Yunan ve Rum'dan daha güzel olmasını temenni etmiş, insanların emri altında emniyette olduğunu, dünya halklarını koruduğunu ve tahtının kutlu olduğunu vurgulamıştır (Oğûlbîg, 1388: 36):

$$
\text { بر بادا همو اره برو بوم* خوشتر ز بلاد آتنه و روم }
$$

“Ülke ve yören daimi olsun, Rum ve Yunan diyarından daha güzel olsun.

Himaye gölgesinde devlet kuşusun ve muhafaza noktasında Allah'ın gölgesisin.

Tahtı kutlu padişahsın, dünyadakilere sığınak olarak geldin.

Bütün insanlar koruman altında, zamanın kötülüğünden emniyettedir.”

Âkâ Hân, Osmanlı devlet adamı, eğitimci ve düşünür Münif Mehmed Paşa'y1 da eserinde "Hazret-i Âsaf Câh-i Meârif Penah" unvanıly yâd etmiş ve ona övgüde bulunmuştur (Oğûlbîg, 1388: 37):

$$
\begin{aligned}
& \text { هر كه در سايه معارف اوست* دشمن و دوستش معارفه جوست } \\
& \text { ذات ضيفش شجر دانش است* مركز ذاتش نسزد جز جنين } \\
& \text { كسب شرف كرده معارف از او *ز آن كه شريف است مكان و مكين }
\end{aligned}
$$

"Onun ilimlerinin gölgesinde bulunan dost ve düşman onunla tanışmak istedi.

Misafir zatı bilginin şeceresidir. Zatının merkezi bundan başkasına yaraşmaz.

İlimler ondan şeref kazandığı için yer ve mekân şereflidir.”

Âkâ Hân, eserinin dibacesinde en son İstanbul'daki İran büyükelçisi Mîrzâ Muhsin Hân'ı İskender' in aynasına ve cihanı gösteren kadehe benzetmiş ve onu methetmiştir (Oğûlbîg, 1388: 41):

$$
\text { اى آسمان جود كه جرخ علو و فضل * هم جون سمند رانم شده زير زين تو }
$$




$$
\text { مهر و وفاو دانش و مردى هر دمى * دلهاى مردمان همه دارد رهين تو }
$$

"Ey fazilet ve yücelik gökyüzü ve ey cömert felek. Çevik ve gösterişli at gibi bacağım senin eyerinin altındadır.

Her zamanın vefa, sevgi, bilgi ve yiğidisin. Bütün insanların gönülleri senin esirindir.

İskender'in aynası ve cihanı gösteren kadehsin. Her bir gösteri senin altın düşüncendendir."

Âkâ Hân, Rıdvân'da İran'dan Rum diyarına yazgısından dolayı seyahat ettiğini ve zamanın o ülkenin sınırları içerisinde kendisini avare ve mahrum ettiğini ifade etmiştir (Oğûlbîg, 1388: 38):

$$
\text { قضا را دست تقدير از ساحت اير ان به سياحت رومم انداخت و زمانه از آن مرز و بوم آوارهو }
$$

"Yazgım beni İran'dan Rum diyarına attı, zaman o ülke ve diyarda beni avare ve mahrum etti...”

Âkâ Hân, Rum diyarını sevinçli, mamur, güler yüzlü gördüğünü, toprak ve havasının temiz ve her tarafının yemyeşil olduğunu, binlerce güzel sesli kuşun etrafta öttüğünü, dallardaki yaprakların saba rüzgârıyla birlikte hareket ettiğini, kendisinin ilk defa seyahate çıktığını, cennet gibi olan Asya'yı yeni gördüğünü, bu diyardaki emniyet ve asayişi daha önce görmediğini beyan etmiştir (Oğûlbîg, 1388: 38):

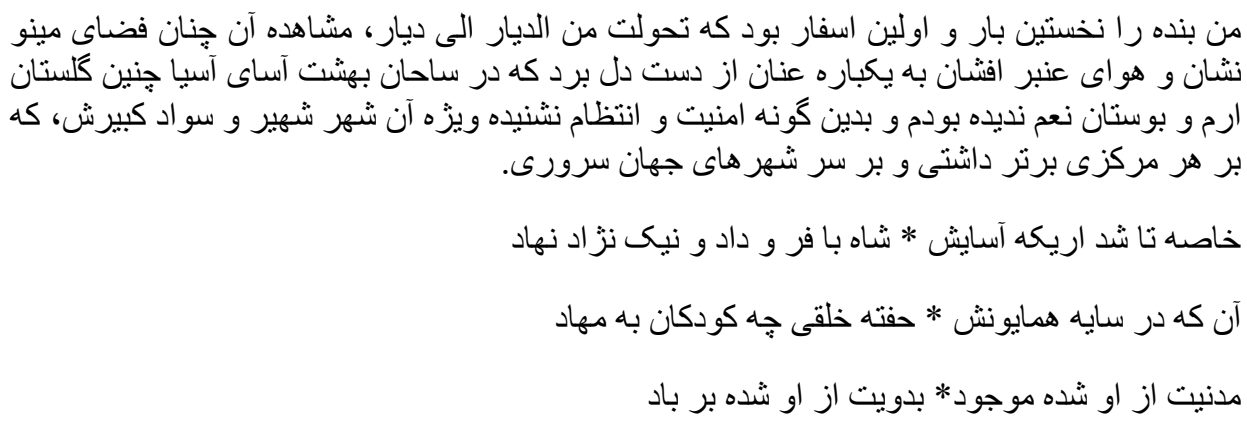

"Bu benim ilk seferimdi, ilk defa bir diyardan ve bir şehirden başka bir yöreye yer değiştirdim, o cennet gibi feza ve güzel havayı görünce, gönül birden elindeki dizginleri kaybetti. Cennet gibi olan Asya'nın meydanında böyle İrem bağı ve nimetlerle dolu bostan görmemiştim ve böyle emniyet ve intizam duymamıştım. 
Özellikle o meşhur ve büyük şehri, her merkezden daha iyi ve bütün dünya şehirlerinden daha emniyetliydi.

Şah özellikle celal, adalet, iyi tabiat ve haşmetiyle asayişi sağladı.

Onun sultanlığının gölgesinde insanlar beşikte çocuk uyutuyor.

Medeniyet ondan hâsıl oldu ve bedevilik ondan yok oldu.”

Bir gün Sâdâbâd'da gittiğini oradaki muhteşem doğayı gördüğünü, kumrunun gül üzerinde öttüğünü, erguvan ağaçlarının yaprak açtığını, reyhanın yeşerdiğini, bahar mevsimi olduğunu ve tahdisi nimet nevinden yukarıda zikrettiğimiz iki beyti Sultan Abdülhamid için söylediğini beyan etmiştir (Oğûlbîg, 1388: 38):

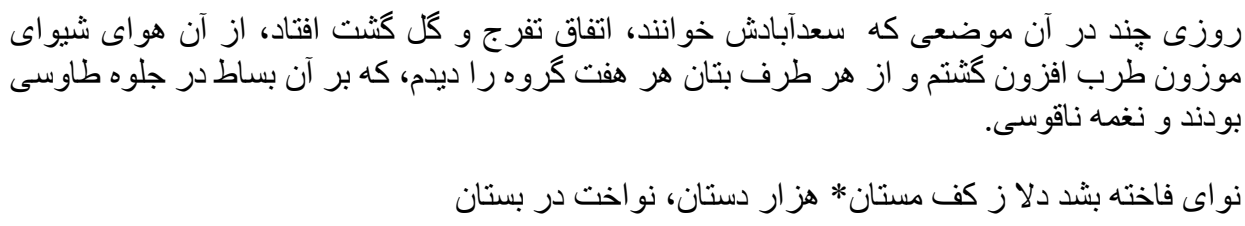

"Birkaç gün Sâdâbâd'a gezmeye ve ferahlamaya gittik, o güzel hava ve kusursuz iklimde mutlu olduk, her tarafta rengârenk tabiatı müşahede ettik, o mahfil ve mecliste tavusun cilvesi ve çanın nağmesi vard1...

Kumrunun ötüşü sarhoşların elinden gönüllerini aldı ve bostanda binlerce hikâye çaldı."

Sa'dî-i Şîrâzî nasıl Gülistân'ın yazılış tarihine işaret etmişse (Dilgoşâ, 1394: 248-268; Yazic1, 1996: 240-41):

$$
\begin{aligned}
& \text { اول اردييشت ماه جلالى* بلبل كَينده بر منابر قضبان } \\
& \text { بر كل سرخ از نم اوفتاده لالى * همجو عرق بر عذار شاهد غضبان }
\end{aligned}
$$

"Celâlî takvimine göre ilkbahar mevsiminin ikinci ayı başıydı, dalların minberlerinde bülbüller hutbeler okuyordu.

Kızıl gül üzerine çiğlerden inciler düşmüştü. Bunlar kızmış bir sevgilinin yanağındaki ter tanelerini andırıyordu.”

Âkâ Hân da aynen onun gibi Rıdvân'ın yazılış tarihine vurgu yapmıştır (Dilgoşâ, 1394: 248-268):

$$
\text { شوكب اسفنديار ماه جلالى * رايت بهمن شكست از بر كهسار }
$$


"Celâlî takvimine göre atlılar İsfend ayında dağlık bölge için Behmen sancağını kirdi.

Renkli mücevherler sayesinde dallar süslendi, yaprak uçuşan lal renkten murassalı oldu."

Sa'dî, Gülistân'in dibâcesinde şu beyitleri dile getirmiş (Dilgoşâ, 1394: 248268):

$$
\begin{aligned}
& \text { كلى خوش بوى در حمام روزى* رسيد از دست مخدومى به دست } \\
& \text { بدو كفتم كه مشكى يا عبيرى* كه از بوى دلايز نو مستم } \\
& \text { بكفتا من كلى ناجيز بودم* وليكن مدتى با كل نشستم } \\
& \text { كمال همنشين در من اثر كرد* وكرنه من همان خاكم كه هست }
\end{aligned}
$$

"Bir gün hamamda efendi bir adam bana bir parça güzel kokulu kil verdi.

O kile: “Misk misin yoksa amber misin, güzel kokundan mest oldum” dedim.

Kil bana cevaben: "Ben adi bir kil idim, ancak bir süre gül ile arkadaş oldum.

Onun güzel kokusu bana sindi, yoksa ben bildiğin toprak parçasıyım.”

Âkâ Hân, Sa'dî'nin bu beyitlerini esas olarak şu beyitleri yazmıştır (Dilgoşa, 1394: 248-268):

$$
\begin{aligned}
& \text { فسرده بلبلى ديدم به بستان * در ايام خزان بر شاخسارى } \\
& \text { بدو كَتم جه شد آن شور و شهناز * كه شهر آثوب خواندى هر كنارى } \\
& \text { بكفتا كان نو اهاى عجب بود* مرا در سايه عشق نحارى } \\
& \text { سليمانم هزار آموخت دستان * وكرنه من يكى مرغ نزارى }
\end{aligned}
$$

“Sonbahar günlerinde bostanda bir dalın üzerinde donuk bir bülbül gördüm.

Ona "sende bulunan o coşku ve şevke ne oldu, oysa eskiden şehrin her tarafını birbirine katardın" dedim.

"Bana aşkın gölgesinde yer veren o acayip ses ve iniltilerdi” dedi.

Süleyman'ım bana binlerce ses öğretti, yoksa ben zayıf, c1lız ve güçsüz bir kuşum.” 
Rıdvân'da tarihi şahsiyetlerin, bilginlerin, şairlerin ve filozofların adlarının geçtiği hikâyeler anlatılmıştır. Eserde Matematikçi Pisagor, Horasan hükümdarı Âsafü'l-ddevle, filozof Aristo, Abbâsî veziri Ahmed b. Hâlid, Nâdirşâh Afşâr'ın oğlu Rızâkulî Mîrzâ Nâdirzâde, Pîş̧âdyân silsilesi padişahı Melik Tahmûrs, hekîm Eflatun, filozof Sokrat, Benî İsrail peygamberi Hz. Yusuf, Abbâsî halifesi Harûn Reşîd, Sâsânî padişahı Melik Pervîz, İskender-i Rûmî, Kâbûs Şemsü'lme'âlî, Fransa hükümdarı V. Louis ve XVI. Louis, Hz. Ali, Sâsânî padişahı Behrâm Gûr, Nâdirşah Afşâr, Rus imparatoru Büyük Peter, Tahran Cuma namazı imamı Nâsrüddin Şah'ın damadı, Mahmûd Şah Kacâr dönemi şairi Yağmâ-i Cendakî, III. Napoleon, Alman imparatoru Friedrich'in adları geçmektedir. Padişaha nasihatlerin çok yer aldığı bu eser, Kaçarlar döneminde Sa dî’nin Gülistân adlı eserine yazılan en iyi naziredir. Eserdeki Arapça kelime ve ibareler sayılmasa, Gülistân'daki gibi hikâyelerin çoğu sade bir üslupla yazılmış, bazı hikâyeler uzun, bazısı da kısadır. Âkâ Hân tıpkı Sa dî gibi Firdevsî'nin Şâhnâme'sinden istifade etmiş, defalarca Bozorgmihr ve Bozorcmihr'den bahsetmiş, Şâhnâme'de geçen âyine-i İskenderi ve nâme-i bâstânî veya nâme-i sâlârnâme gibi hamâsî kalıplardan yararlanmış ve bazı beyitlerini mütekârib bahriyle yazmıştır (Dilgoşâ, 1394: 248-268; Oğûlbîg, 1388: 21-210; Serefzârî \& Dilgoşâ, 2015: 45-59).

Eserde manzum ve mensur 353 hikâye bulunmaktadır. Hikâyelerde hikmet, ögüt, latifeler yer almaktadır. Özellikle hâtime bölümünde çok sayıda hikmet, öğüt, edep, politika ve siyaset ile ilgili nükteler bulunmaktadır. Esere bakıldığında müellifin tarih, hikmet, müzik, siyaset ve diğer ilimleri iyi bildiği görülmektedir. Ahlakî ve ilmî bir mecmua olan bu eser, diğer ahlaki eserler gibi muhatabına bıkkınlık vermemektedir. Bazen hicivli bir eda takınan müellif eserindeki bazı hikâyelerin muhatabını doğrudan ifade etmemiştir. Bu hikâyelerin bazısı bazen kitabı okuyana ve bazen de şairin kendisine hitap etmektedir. Müellif doğrudan Avrupalılarla fikir alışverişinde bulunmuş ve hikâyelerde Fransızca, Arapça ve Türkçe bildiğini ifade etmiştir. Müellifin asıl hedefi Sa'dî'yi taklit etmek olduğu için kinaye, îcâz ve diğer edebi sanatlar akıcı söz söylemesini engellemiştir. Eleştirel bir dile sahip olan eserde çok sayıda Arapça kelime var ve bu durum eserin kusurlu sayılmasına neden olmuştur. Eserde tasavvufî̀ 1stılahlar yer almaktadır (Dilgoşâ, 1394: 248-268; Serefzârî \& Dilgoşâ, 2015: 45-59).

Âkâ Hân eserinde Osmanlı sultanları, Kostantiniye, Türk şehzadeleri, Ayasofya Camii ve Osmanlı elçileri hakkında bazı hikâyeler nakletmiştir (Oğûlbîg, 1388: 141, 139, 133, 122, 120, 99, 62, 49).

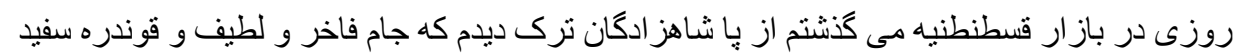

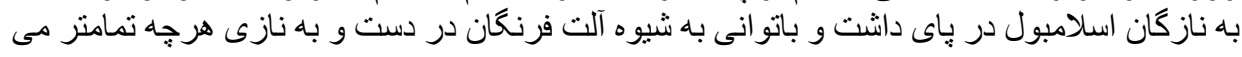




$$
\begin{aligned}
& \text { خراميد و از كمال بهجتى كه مر او را بود به هرطرف كه مى كنشت همه كس در سير جمالش خيره }
\end{aligned}
$$

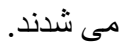

$$
\begin{aligned}
& \text { هرجا كه كنشتى آن بريروى * ياقوت كرفت از او شفق وام } \\
& \text { از عكس رخش زمين شدى لعل* و ز رنح لبش زمانه مى فام }
\end{aligned}
$$

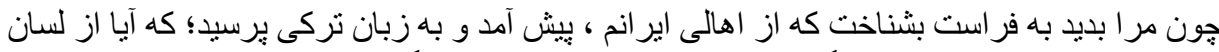

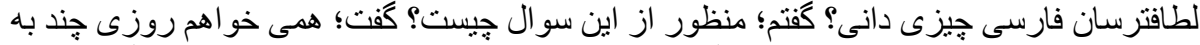

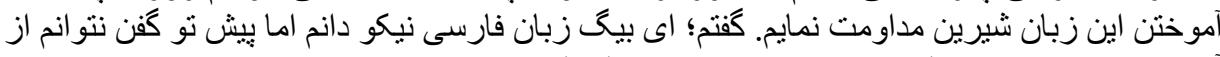

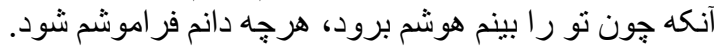

$$
\begin{aligned}
& \text { مر ا بيش رخت بودن محال است* تو ميآى، از من ميرود هوش }
\end{aligned}
$$

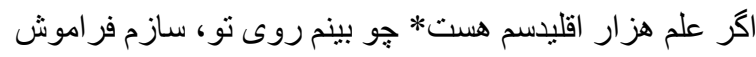

"Bir gün Kostantiniye pazarında geçerken, Türk şehzadelerinden birini gezerken gördüm. Latif ve güzel elbise ve beyaz kunduralarıyla İstanbul sokaklarını arşınlıyordu. Elindeki Frenk tarzı aletle olabildiğince yavaş hareket ediyordu. Kemal derecedeki yakışıklılı̆̆ sebebiyle geçtiği her yerde bütün insanlar onun cemaline bakıyordu.

O peri yüzlünün geçtiği yerde, yakut ondan sevinci ödünç alır.

Yüzünün aksinden zemin kırmızıya boyanır ve dudağının renginden zaman belli olur.

Beni görünce, ferasetiyle İranlı olduğumu anladı, öne geldi ve Türkçe şöyle dedi: Latif olan Farsça dilinden başka bir şey biliyor musun? Dedim: Bu sorudan maksadın ne? Dedi: Her gün bu tatlı dili öğrenmek için çalışmak istiyorum. Dedim: Ey Bey, Fars dilini iyi biliyorum, ancak senin yanında ondan söz söyleyecek takatim yok, çünkü seni görünce kafamda akıl kalmıyor ve bildiğim her şeyi unutuyorum.

Bana senin yüzünün önünde bulunmak muhaldir. Sen gelince, benden akıl gider.

Aklımda binlerce ilim olmasına rağmen, senin yüzünü görünce hepsini unutuyorum.”

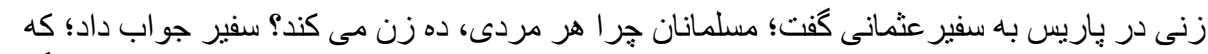

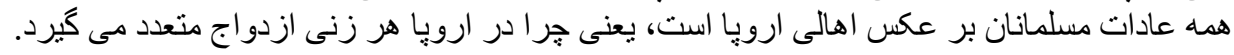

$$
\text { كفت مسيو به مادام خود روزى* كه تو را شوهر من،اى مادام }
$$




$$
\text { تو جر ا مايلى سوى ديكر ان* كفت؛؛ ز آنرو كه تشنه ام مادام }
$$

"Paris'te bir kadın Osmanlı elçisine şöyle dedi: Müslüman ülkelerde neden her erkek on kadınla evleniyor? Elçi ona şöyle cevap verdi: Müslümanların bütün adetleri Avrupalıların aksinedir, yani niçin Avrupa'da kadınlar birden çok erkekle evleniyor?

Mösyö bir gün hanımına şöyle dedi: Ey hanım ben senin kocanım.

Sen neden başkalarına meylediyorsun, hanım şöyle dedi: çünkü sürekli susuzum.”

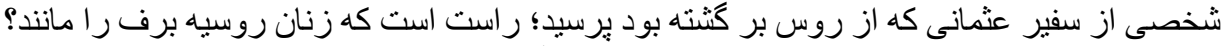

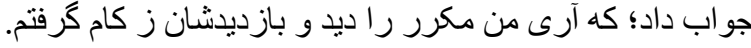

$$
\begin{aligned}
& \text { نورم از جشم برد و هوش از سر * خانم مسقوى مكر برف است }
\end{aligned}
$$

"Bir kimse Rusya' dan dönen bir Osmanlı elçisine şöyle sordu: Gerçekten Rus kadınları kar gibi beyaz mı? Elçi cevap olarak: Evet, ben defalarca gördüm ve onları ziyaret etmekten zevk aldım.

Kar gibi beyaz olan Moskof karısı gözümdeki nuru ve kafamdaki aklı götürdü.”

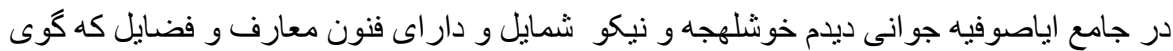

$$
\begin{aligned}
& \text { فر است از ابناى زمان ربوده و بر بر هان كياست به جهانيان نمودها } \\
& \text { انو ار معارفش درخشان* جون طلعات آفتاب رخشان }
\end{aligned}
$$

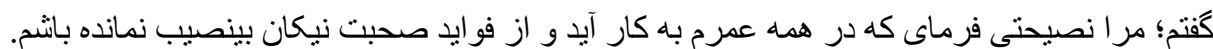

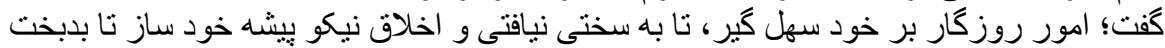

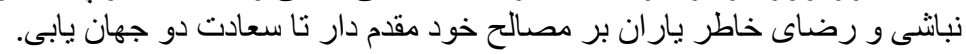

$$
\begin{aligned}
& \text { اي كه خو اهى سعادت دو جهان* مكن از نكبت جهان تتويش } \\
& \text { خلق نيكو نماى يبشه خويش* تا نكردد دلت ز سختى ريش } \\
& \text { ده مزيت رضاى ياران را* دايما بر مر اد خاطر خويش }
\end{aligned}
$$

“Ayasofya Camii'nde güzel konuşan, şekil şemaili iyi, ilim ve faziletleri bilen, zamanın bilimlerinden haberdar ve dünyadaki burhandan agâh olan bir gence rastladim.

Maarifinin 1şığı güneşin siması gibi parlaktı. 
Dedim: Bana bütün ömrüm boyunca işime yarayacak bir nasihat et de iyilerin sohbetinden nasipsiz kalmayayım. Dedi: Günlük işleri kendine kolay kıl ki, zorluk çekmeyesin ve iyi ahlakı meslek edin ki, bahtsız olmayasın. Dostların hatır rızasını kendi çıkarının önünde tut ki, iki cihanda saadete kavuşasın.

Ey her iki cihanın saadetini isteyen kimse, dünyanın musibete giriftar olmasina neden olma.

İnsanlara iyilik etmeyi meslek edin ki, gönlün zorluktan incinmesin.

Dostların rızasının meziyetini daima kendi gönül muradından üstün tut.”

$$
\begin{aligned}
& \text { نايليون فر انسه از سلطان عثمانى برسيد؛ييغمبر شما با كدام نردبان مر اج كرد؟ كفت با همان نردبانى } \\
& \text { كه بيغمبر شما فرود خو اهد آمد. } \\
& \text { هر جزايى هست بر طبق فعال* هر جو ابى هست بر شكل سو ال }
\end{aligned}
$$

"Fransız Napolyon, Osmanlı sultanına: Sizin peygamberiniz hangi merdivenle Miraca çıktı? Osmanlı sultanı: Sizin peygamberinizin aşağı ineceği merdivenle.

Her ceza aynı eylemle yanıt bulur. Her suale aynı şekilde cevap verilir.”

Âkâ Hân, Rıdvân'da Yağmâ-i Cendekî, Emir Hüsrev-i Dihlevî ve Ubeyd-i Zâkânî gibi meşhur İranlı şairler ile ilgili bazı hikâyeler nakletmiştir (Oğûlbîg, 1388: 90, 132, 73):

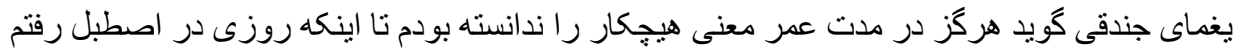

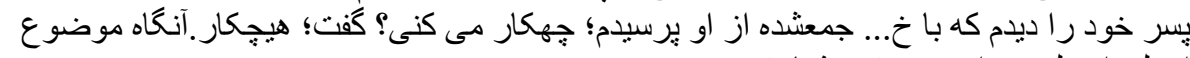

$$
\begin{aligned}
& \text { اصلى اين لغت را به درستى بشناختم. } \\
& \text { جو نكه ديدم جمال دلكش تو * معنى هيج را بدانسنم }
\end{aligned}
$$

"Yağmâ-i Cendekî şöyle diyor: Bir gün ahıra gidip, çocuğumu uygunsuz bir şekilde görüp, ona ne yapıyorsun? deyince, bana cevaben "hiçbir şey" demeden önce, ömrüm boyunca "hiçbir şey" kelimesinin anlamını bilmiyordum. O olaydan sonra bu lügatin asıl manasını tam anlamıyla kavradım.

Gönül, çekici cemalini görünce, "hiçin” manasını bildim.”

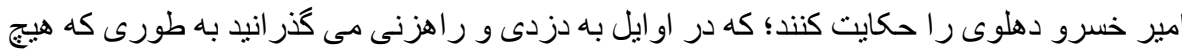

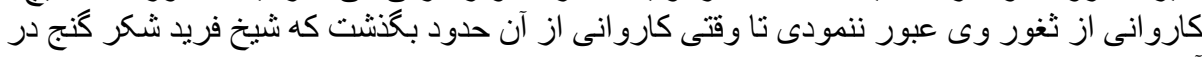

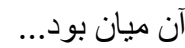


"Emir Hüsrev-i Dihlevî hakkında şöyle söylenir: İlk önceleri hırsızlık ve haydutlukla uğraşırdı, hiçbir kervan onun çizdiği sınırların içinden geçmezdi. Bir gün Şeyh Ferîd-i Şeker Genc'in de içinde olduğu bir kervan bu sınırı ihlal etti...”

$$
\begin{aligned}
& \text { همانا قصده عبيد زاكانى را نثنيده اى كه جون از شاخه فضل و هنر اقتطاف ثمرى نكرد فور ا تبديل } \\
& \text { مسلك نموده و طريقه هزل بيموده. } \\
& \text { تا به كى از يى هنر يوى * بشنو اين، از عبيد زاكانى }
\end{aligned}
$$

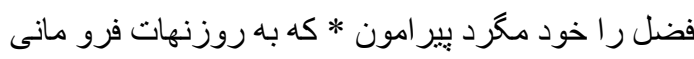

$$
\begin{aligned}
& \text { دايما فحش و هزل بيشه نما* تا كه داد از زمانه بستانى }
\end{aligned}
$$

“Ubeyd-i Zâkânî’nin şu kıssasını dinlemedin mi? Yönetimden hüner ve faziletine rağmen beklediği ilgiyi görmeyince, hemen şiir tarzını değiştirip, hezel tarzında şiirler yazmış.

Ne zamana kadar hünerin peşinden gideceksin, Ubeyd-i Zâkânî'den şu sözü dinle:

Sadece faziletinin çevresinde dolanma, yoksa bir deliğe tıkılıp kalırsın.

Zamandan adalet bulmak için daima hezel ve hicvi meslek edin.”

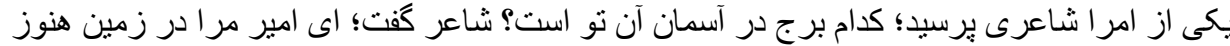

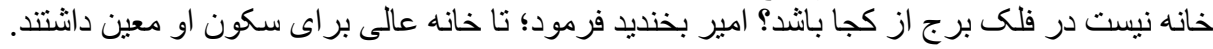

$$
\begin{aligned}
& \text { بر فلى از كجانو انم تاخت* من كه كار زمين نكردم راست } \\
& \text { از نو آر ايش جهان نايد* كه نيارى بساط خود آراست }
\end{aligned}
$$

"Emirlerden birisi bir şaire sordu: Gökyüzündeki hangi burç senindir. Şair: Ey emir, benim hala yeryüzünde bir evim yok, gökyüzünde burcum nasıl olsun? Emir güldü ve kendisine güzel bir ev yapılmasını ferman etti.

Gökyüzüne nasıl çıkayım, daha yeryüzündeki işi doğru dürüst yapmadım.

Kendi sofranı süslemeden, dünya sofrasını süsleyemesin.”

Âkâ Hân eserinde birçok peygamber kıssasına ve dini hikâyelere değinmiştir (Oğûlbîg, 1388: 46, 95, 128):

$$
\begin{aligned}
& \text { يو سف عليه السلام را كفتند؛ با اين كه همه خر اين مصر در كف تو است جر ا شب كرسنه خو ابى؟ }
\end{aligned}
$$

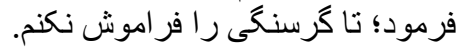

$$
\begin{aligned}
& \text { اى سير! غم كرسنحانت * هركز نشود عزيم جانت }
\end{aligned}
$$


الا كه شوى كرسنه روزى* محروم شوى ز رزق و روزى

“Hazreti Yusuf’a dediler: Mısır'ın bütün hazineleri elindeyken neden gece aç yatıyorsun? Hz. Yusuf: Açlığı unutmamak için.

Ey tok kimse, açların kederi asla canını acıtmayacak.

Ancak mutlaka bir gün acıkacaksın, azık ve rızıktan mahrum kalacaksın.”

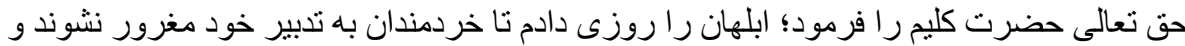

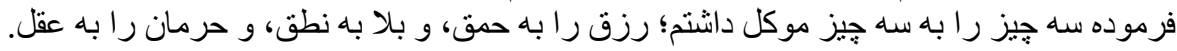

$$
\begin{aligned}
& \text { به نادان رزق افزون تر نمايد * كه تا دانا به دانش كم كند ناز } \\
& \text { خردمندى است جفت نامر ادى* در اين عالم جنين بوده است آغاز }
\end{aligned}
$$

"Yüce Allah, hazreti Kelîm'e şöyle emretti: "Akıl sahipleri ileri görüşlülükleriyle mağrur olmasın diye aptallara rızık verdim" ve şöyle ferman etti: "Şu üç şeyi üç şeye bağlı kıldım: rızkı ahmaklığa, belayı konuşmaya, mahrumiyeti akılla.

Bilgin bilgisiyle daha az nazlansın diye cahile daha fazla rızık verilir.

Bu âlemde ilk başlardan beri murat ile muratsızlık birliktedir.”

$$
\begin{aligned}
& \text { خطبى را برسيدند؛ كه مسلمانى جِيست؟ كفت؛ من مردى خطيبم مر ا به مسلمان جهه؟ } \\
& \text { به كنج خانه عزلت نشينم * كه هيج آسودگى به زين نباثد } \\
& \text { مر ا نانى و آبى ز اين جهان بس * دكر كارى به كفر و دين نباشد }
\end{aligned}
$$

"Bir hatibe sordular: Müslümanlık nedir? Hatip: Ben hatibim, Müslümanlığın ne olduğunu nereden bileyim?

Evin köşesinde uzlete çekilirim, çünkü bundan daha rahatı yoktur.

Bana bu dünyada sadece bir ekmek ve biraz su kâfidir, artık küfür ve dinle işim yoktur.”

Rıdvân'da Sokrat, Emîr Tîmûr-i Gûrgân ve İskender hakkında güzel hikâyeler anlatılmıştır (Oğûlbîg, 1388: 45, 107, 76):

$$
\text { ريكى در زندان نزد سقر اط رفته، كفت؛ ملى تو را خو اهد كثت. سقر اط فرمود؛ او را هم اجل }
$$




$$
\text { تو هم ایى مبر نامور روزى * كثته خواهى شدن به تير اجل }
$$

"Biri zindanda Sokrat'ın yanına gitti ve ona: "Melik seni öldürecek" dedi. Sokrat: “Onu da bir gün ecel öldürecek” buyurdu.

Günahsızların kanını dökmekle dünyada ecelin emiri olursun.

Sen de ey meşhur emir, bir gün ecel okuyla öldürüleceksin.”

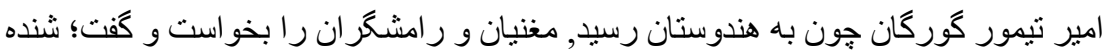

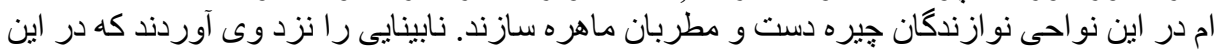

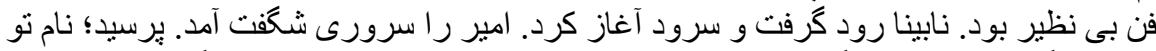

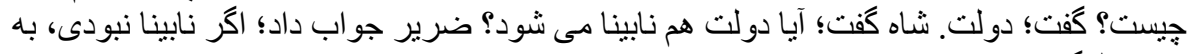

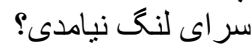

$$
\begin{aligned}
& \text { هست كيتى جه مجمع الاشتات* جمع و وحدت ثمر باشد } \\
& \text { ذره ذره اندر اين عالم* جاذب سنخ يكديكر باثند }
\end{aligned}
$$

“Emîr Tîmûr-i Gûrgân, Hindistan'a ulaşınca şarkıcı ve çalgıcıları istedi ve "Bu diyarda çok mahir çalgıcı ve şarkıcıların var olduğunu duyduğunu söyledi. Tîmûr'un yanına bu işte maharetiyle meşhur olan âmâ birini getirdiler. Âmâ rûd aletini aldı eline ve çalmaya başladı. Emîr zevkten dört köşe oldu. Şöyle dedi: "Senin adın nedir?" Çalgıc1: "Devlet" dedi. Emîr: "Devlet de kör olur mu?" dedi. Âmâ çalgıcı şöyle cevap verdi: Eğer kör olmasaydın, özürlünün sarayına gelmezdin?

Dağınık haldeki bir mecmuayı andıran bu dünya, birlik ve vahdeti netice vermektedir.

Bu âlemdeki her bir zerre birbirinin aslını cezbetmektedir.”

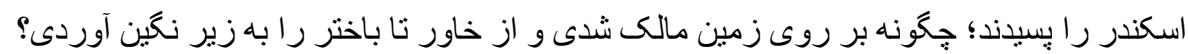

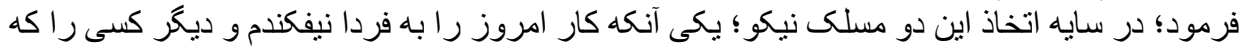

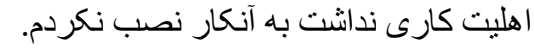

$$
\begin{aligned}
& \text { وه جهه خوش آمد مر ازين بيت نغز * كه همى مى خو اند بيرى مالدار } \\
& \text { ار براى كار بايد شخص جست* نيز براى شخص بيدا كردكار }
\end{aligned}
$$

"İskender'e "nasıl yeryüzüne malik oldun ve doğudan batıya kadar her yeri ele geçirdin" diye soruldu. İskender: Şu iki güzel haslet sayesinde: Birincisi bugünün işini yarına bırakmadım ve diğeri de bir işte ehliyeti olmayan kimseye iş emanet etmedim. 
Ah, mal sahibi pîrin daima okuduğu şu latif beyit ne güzel geldi.

Eğer bir iş için bir şahıs aranacaksa, o şahsın deneyimli olmasına dikkat edilmeli."

Âkâ Hân'ın hicivli ve mizahi bir dile sahip olduğu Rıdvân'daki bazı hikâyelerde açıkça görülmektedir (Oğûlbîg, 1388: 133):

$$
\begin{aligned}
& \text { زنى خوشروى در بيش كثيش كناهان خود را مى كفت؛ بِ إز اتمام اقرار كشيش از نامش بِرسيد؟ زن }
\end{aligned}
$$

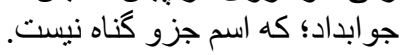

$$
\begin{aligned}
& \text { نام خود را شمرد جزو كناه * آنكه نارد كنه خود به شمار } \\
& \text { زاهدان توبه كنند از عصيان* عارف از هستى خود استغفار }
\end{aligned}
$$

"Güzel bir kadın bir keşîşin yanında günahlarını söylüyordu. Günahlarını söyledikten sonra keşiş adını sordu? Kadın ona cevaben: İsim söylemek günaha dâhil değildir.

Günahlarını söylemeyen kimse, ismini günahlarının bir parçası gibi söyledi.

Zâhitler isyandan tövbe ederler, ârif ise kendi varlığından istiğfar eder.”

$$
\begin{aligned}
& \text { دو نن به هو ایى زنى جنگ شمشير مى كردند. زن كفت؛ اى جو ان مردان، وصال من به سيم و زر }
\end{aligned}
$$

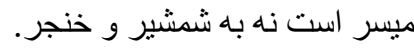

$$
\begin{aligned}
& \text { هر كه جويد ز ماه رويان كام* زر همى بايدش نه زارى و زور }
\end{aligned}
$$

“İki kişi bir kadın için kılıçla dövüşüyordu, kadın şöyle dedi: Ey gençler, benim visalim altın ve gümüşle mümkündür, kılıç ve hançerle değil.

Her kim güzel yüzlülerden mutluluk arıyorsa, kendisine inlemek ve güç değil, altın lazımdır."

Âkâ Hân, mensur hikâyelerin yanında yedi manzum hikâye de yazmıştır (Oğûlbîg, 1388: 76):

$$
\begin{aligned}
& \text { تنى از مردم كرمان، از شهر * شد كريزان به سوى كوه رمان } \\
& \text { بريكى سنى به سر جشمه نحاثت * اين دو بيت از ره تصديق و كمان } \\
& \text { خرس از اين كوه، رمان كثثت ولى* من ستوه آمدم از خلق زمان } \\
& \text { مكر از شر ددان در اين كوه* روزكى جند شوم جفت امان } \\
& \text { همجو عيسى كه زست احمق * روز و شب بود به سوى كوه روان }
\end{aligned}
$$


"Kirmân şehrinden bir kimse, Român dağına doğru kaçtı.

Çeşme başındaki bir taşa şu iki beyti tasdik ve onay işareti olarak yazdı.

Ayı bu Român dağında dolaşıyor, ancak ben zamane halkından bıktım. kalırım

$\mathrm{Bu}$ dağda yırtıcıların şerri olmasa, birkaç gün karı kocadan ayrı esenlikte

Hz. İsa da ahmakların elinden gece gündüz dağa doğru giderdi.”

Rıdvân'ın son babında Âkâ Hân hikmet, latife, ögüt, siyaset, tarif, tembih, temsil ile ilgili birçok söz söylenmiştir (Oğûlbîg, 1388: 151-163):

$$
\begin{aligned}
& \text { حكت؛ مر اد آدمى در قيد دل او است جون فانش كند مر غى را ماند كه از ققس بريده بانثد } \\
& \text { راز خود تا به كس نكردى باز * مالك راز خويشتن باشى } \\
& \text { جون شود فاش مالك تو بود* تو اسيرش به جان و تن بانشى }
\end{aligned}
$$

"Hikmet: İnsanın muradı gönlünde saklıdır. O sırrı aşikâr edince, bir kuş gibi kafesten uçup gider.

Sırrını başkasına söylemediğin sürece, sırrının malikisin.

Senin malik olduğun ifşa olunca, sen ona can ve ten ile esir olursun.”

$$
\text { حرد دانا ران دانا كسى است كه از آموختن ننى نبآرد و از آموز انيدن دلتنى نباثد. }
$$

"Hikmet: Bilgin kimse, öğrenmekten utanmaz ve öğretmekten usanmaz.

Bilgin adam, öğreticinin dudağından istifade etmekten asla utanmamalı.”

$$
\text { حكت؛ فيثاغورس فرمايد؛ هر جيز محتاج عقل و دانش است، جز بخت }
$$

"Hikmet: Fisagors şöyle buyurmuş, talihten başka her şey akıl ve bilgiye muhtaçtır."

$$
\text { حكمت؛ صيد مر غان اكر به دام بود* دام آز ادكان ادام بود }
$$

"Hikmet: Kuşlar tuzak ile avlanılır ve özgür olanların tuzağıysa idamdır.”

$$
\text { لطيفه؛ نزد اثر اف، اشرف اوصاف * اقتصاد است وانكهى انصاف }
$$

"Latife: Eşrafın nazarında en şerefli vasıf, iktisat ve insaftır." 


$$
\text { لطفيفه مردم را بد خود كفتن آسانتر است از خاموش نشستن. }
$$

"Latife: İnsanlara kötülüklerini söylemek, sessiz oturmaktan daha kolaydır.

Her ne kadar kendi haklarında olsa da müfsitlere fesat ve fitne güzeldir.”

$$
\text { هند؛ هر كه نان خود را به آفتاب كذارد خود در سايه نشيند. }
$$

“Öğüt: Her kim ekmeğini güneşe koyarsa kendisi gölgede oturur.

Allah'ın rızası için çalışmak hiçbir kötülüğe bulaşmamaktır."

$$
\text { يند؛ دوست به دست آوردن آسان است و نحاه داشتن دشوار. }
$$

“Öğüt: Bir kimseyi dost edinmek kolaydır, ancak onu muhafaza etmek zordur.

Dostluk ilk başta göze kolay göründü, ancak sonunda ten ve canı eziyetten yakt1.”

$$
\text { تعريف؛ اقتصاد آن بود كه مرد جو اد * در همه حال بنكرد اطر اف }
$$

“Tarif: İktisat civanmert insanın her hal üzere etrafına bakmasıdır.

İtidalin manası da ne cimri olmak ve ne de israf etmemektir.”

$$
\text { سياست؛ مرد كاهل را نبايد داد جيز * بلكه مى بايد به كارش داشتن }
$$

"Siyaset: Tembel adama bir şey vermek yerine onu çalışmaya zorlamak gerekir."

$$
\text { تتبيه؛ از نكويى سباس نارد، ليك* هم به قطع عطا شود رنجور }
$$

"Tembih: İyilikten minnet hâsıl olur, ancak bağışın kesilmesiyle hoşnutsuzluk ortaya çıkar."

$$
\text { تنثيل؛ نيكبخت آنكه از نكويى خلق * دشمنان را به خود نمايد دوست }
$$




$$
\text { دشمن از بهر خود تر اشيدن* شيوه مرد عاجز بدخوست }
$$

“Temsil: Mutlu kimse, iyi yaratılışı sebebiyle düşmanları kendisine benzetip, dost edendir.

Acizlik ve kötü ahlaktan dolayı dostu düşman etmemek gerekir, hatta bu iş iyi değildir.

Kendisi için düşman üretmek, aciz ve güçsüz adamın tarzıdır.”

\section{SONUÇ}

Osmanlı sultanlarının Fars dili ve edebiyatına duyduğu büyük ilgi sayesinde birçok İranlı şair ve yazar Osmanlı topraklarını yurt edinmiştir. Bu seçkin kişiler Farsça'nın yanında Türkçe şiirler yazmış, dinî ve edebî konularda birçok eser kaleme almış, Anadolu'nun bilim ve kültür merkezi haline gelmesini sağlamıştır. Sa'dî’nin yaşamından sonra Gülistân tarzında birçok eser yazılmıştır. Çok sayıda yazar makâme türünde olan bu eserden daha iyisini yazmaya çalışmış ve bu konuda Fars ve Türk edebiyatında başarılı örnekler verilmiştir. Ancak hiçbirisi Gülistân'ın seviyesine ulaşamamıştır. Gülistân'ı taklit edip, Rıdvân'ı yazan Âkâ Hân daha önceki şair ve yazarların eserlerinden alıntılar yapmış, hadislerden, ayetlerden, menkıbelerden, büyük insanların sözlerinden, gezip gördüğü yerlerden, okuduğu kitaplardan, tanıştığ 1 insanlardan, girdiği farklı çevrelerden istifade etmiştir. Âkâ Hân'ın Rıdvân'daki her söz, beyit ve hikâyesi bilgelik doludur. Taklidi ve yavan bir üsluba sahip olan bu eser, manzum ve mensur olarak yazılmıştır. Eserdeki bazı hikâyelerde Osmanlı ve İran'daki sosyal durum, düşünce ve görgü kuralları ifade edilmiştir. Rldvân sadece şiir ve hikâyelerden oluşmamış, baştan sona hikmet, latife, nasihat ve vecizelerden meydana gelmiştir. Âkâ Hân eserindeki hikâyelerde hem geçmişten örnekler vermiş, hem de kendi hayatındaki mevzulara değinmiştir. Eserdeki nükte ve hikâyeler her zaman bölümlerin muhtevasıyla bağdaşmamaktadır. Bölümlerde günlük hayatta karşılaşılan olaylar dikkate alınmış, nükte ve hikâyeler beyitlerle süslenmiştir. Eserde devrin önemli adamları övülmüştür.

\section{KAYNAKÇA}

Âdemiyyet, F. (1357). Endîşehâ-yı Mîrzâ Âkâ Hân-i Kirmânî. İntişârât-i Peyâm.

Âryanpûr, Y. (1387). Ez Sabâ tâ Nîmâ. İntişârât-i Zevvâr.

Aydın, Ş. (2010). Türk edebiyatında Farsça divan ve divançeler. İskenderiye Kitaplığı.

Değirmençay, V. (2013). Farsça şiir söyleyen Osmanlı şairleri. Atatürk Üniversitesi Yayınlar1. 
Dilgoşâ, A. B. (1394). Bâzhân-i Kitâb-i Ridvân Risâle-i Münteşir Neşode ez Mîrzâ Abdülhüseyîn Hân Berdesîrî-i Kirmânî, Peyâm-i Bahâristân, 7 (25), 248-268.

Kartal, A. (2008). Anadolu Selçuklu devleti döneminde dil ve edebiyat, Divan Edebiyatı Araştırmaları Dergisi, 1 (1), 95-168. https://doi.org/10.15247/dev.22

Kaska, Ç. (2019). Mîrzâ Habîb-i İsfahânî ve İstanbul'da Yayınladığı Eserleri, Bilecik Şeyh Edebali Üniversitesi Sosyal Bilimler Dergisi, 4 (2), 538-551. https://doi.org/10.33905/bseusbed.559022

Muhammedî, R. (1383). Ridvân, Dânişnâme-i Edeb-i Fârsî/ Edeb-i Farsî Der Ânâtûlî ve Bâlkân (s. 417-419). Sâzmân-i Çâp ve İntişârât-i Vezâret-i Ferheng ve İrşâd-i İslâmî.

Oğûlbîg, S. Y. (1388). Tashîh-i Nusha-i Hatî-i “Rıdvân” Eser-i Mîrzâ Âkâ Hâni Kirmânî, [Yayınlanmamış Yüksek Lisans Tezi], Dânişgâh-i Peyâmnûr.

Özgüdenli, O. G. (2008). İstanbul Kütüphanelerinde Bulunan Farsça Yazmaların Öyküsü: Bir Giriş, Tarih Araştırmaları Dergisi, 27 (43), 1-76. https://doi.org/10.1501/Tarar_0000000400

Riyâhî, M. E. (1995). Osmanlı Topraklarında Fars Dili ve Edebiyatı, Çev. Mehmet Kanar, İnsan Yayınları.

Serefzârî, A. ve Dilgoşâ, A. B. (2015). Bâznigerî-i Câyigâh-i Sa'dî der Endişehâi Rûşenfikrân-i Asr-i Meşrûte. Pejûheşnâme-i Târîh, 10 (38), 45-59.

Yazıcı, T. (1996). Gülistân, Türkiye Diyanet Vakfi İslâm Ansiklopedisi (ss. 24041). Türkiye Diyanet Vakfı Yayınları. 